\title{
OUTCOMES OF CALYCANTHUS L. INTRODUCTION INTO THE CONDITIONS OF VOLYN UPLAND AND POSSIBILITIES OF ITS USAGE IN THE GREENERY PLANTING
}

\section{Gavrylyuk Olga}

Lesya Ukrainka Eastern European National University, Lutsk, Ukraine

Received 25. 6. 2017

Revised 29. 6. 2017

Published 27. 11. 2017

The paper presents results of researching of the bioecological features of three Calycanthus L. species, introduced into the conditions of the Volyn Upland. It is proved that the rhythm of seasonal development of the studied species in the conditions of introduction is stable, regardless of the temperature fluctuations the plant bloom and fruit annually. It has been proved, that under the conditions of introduction the plants have passed a complete cycle of growth and development, which is evidence of their adaptation to the regional conditions. The study of the ability of introduced species to seed and vegetative reproduction showed that first one is more promising. The success of introduction and their future usage in greenery plantings have been evaluated. These plants are characterized by high and average adaptation - IV-II and high and satisfactory acclimatization - 68-91 points. According to the assessment of their viability, it should be noted that the first group of perspective should include species of Calycanthus fertilis Walter, which plants have a higher score of the winter resistance. Ecological plasticity is a key factor of introduction success for North America plant species under introduction into the conditions of the Volyn Upland. North-American woody plants can be widely used not only at the locations of natural growing, but also in conditions of introduction. The evaluation of prospects of these species has a great significance for their wide distribution and introduction into the culture. Based on our observations, all species of Calycanthus L. deserve attention and a score of 4 was obtained on the decorative scale.

Keywords: introduction; Calycanthus L.; adaptation; development cycle; acclimatization; Volyn Upland

\section{Introduction}

Critical to the success of introductions is the selection of the most appropriate genetic forms in the species range and the maternal population that is as close as possible to the ecological conditions of growth to the site of introduction. The introduction of plants in most aspects of their activities is a regional phenomenon, and its application is largely determined by the possibilities of the localization where plants are introduced into the culture. The introductory opportunities of open ground are a combination of all climatic and soil factors in the area where the introduction is located, taking into account the factors of the anthropogenic impact and other factors of biotic and abiotic influence (Базилевская, 1964).

The long experience of introduction in the botanical gardens of our country allows us to consider the North America to be the largest source of introduction for the biological enrichment of 
dendroflora (Гурский, 1957.). Of great interest in this respect are species of the genus Calycanthus L., which are a promising decorative culture for the conditions of the Volyn Upland. It is difficult to say why these plants are still rare: they are more enduring than many common heat-loving shrubs (Хессайон, 2006).

Species of the genus Calycanthus can be used as the ornamental and beautiful flowering plants for use in various types of landscape compositions. The creation of plantings of such plants is of particular interest since they have a long-life cycle and landscape solutions of them are not timeconsuming, but durable.

The objective of the work is based on the comprehensive study of introduced species of the genus Calycanthus to assess the prospects of their introduction into the culture in the conditions of the Volyn Upland, to determine the success of the introduction of these species, depending on the ecological and biological features and to allocate a promising assortment for use in picturesque landscapes.

\section{Materials and methodology}

The objects of study were 3 species of the genus Calycanthus spp.: Calycanthus fertilis Walt., Calycanthus floridus L. and Calycanthus occidentalis Hook. et Arn., which are on an introductory test at an agrobiological station within the botanical garden of the Lesya Ukrainka East European University.

For the successful introduction of plants, it is important to study the rhythm of development, since the features of the passage of the phenological phases reflect the process of introductory adaptation of plants (Ворошилов, 1960) Regular passage of the introducent all phases of development, annual flowering, the formation of quality seeds are the signs of the success of adaptation to new environmental conditions (Мамаев, 1991).

Phenological observations were carried out by the method of phenological observations in the botanical gardens of the USSR. The method of R.H. Turetskaya was used in studies on vegetative reproduction. The method of integral digital assessment of the success of the introduction of S.V. Sidneva and P.I. Lapin (Лапин и Сиднева, 1973) was used to assess the success of the introduction of species of the genus Calycanthus. Seven main indicators were selected: the degree of annual ripening of shoots, winter hardiness, the conservation of plant habit, the ability to shoot, the regularity of shoot growth, the capacity for generative development, the methods of reproduction of the plants were under the study in the region of introduction.

To assess the adaptation the determination of acclimatization number proposed by Kohno was taken into constant conditions of the Volyn Upland. The method developed by M.A. Kokhno (Koxнo и Курдюк, 1994) and A.A. Kalinichenko (Калиниченко, 1978) were conducted to assess the success of adaptation. On adaptive indicator was used to evaluate the level of adaptation. It is the result of multiplying winter hardiness, drought resistance, reproductive capacity. The estimation of plant drought resistance was determined by a six-point scale S.S. Pyatnitsky (Пятницкий, 1961); Winter hardiness - according to the five-point freezing scale of M.K. Vekhov (Вехов, 1957). Estimation of decorativeness was determined according to the A.A. Kalinichenko scale (Калініченко, 2003).

\section{Results and discussion}

Species of the genus Calycanthus grow naturally in the southeast (Calycanthus fertilis, Calycanthus floridus) and in the west (Calycanthus occidentalis) of North America. Deciduous shrubs are 2-3 m high, sometimes up to $6 \mathrm{~m}$. The plants have a rounded crown, single dark purple flowers $2-7 \mathrm{~cm}$ in diameter, which mainly appear before the leaves bloom (Морщихина, 1980). 
An essential indicator of the adaptive capabilities of plants under the conditions of introduction is the completeness of their passage of phenological phases. As a result of the analysis of the data of phenological observations, it has been established that all the species we studied under the conditions of the Volyn Upland undergo a full cycle of seasonal growth and development. It is established that the beginning of vegetation of plants is determined by the sum of effective temperatures and the average daily air temperature. To start the Calycanthus growth process, it is necessary that the average daily air temperature reaches $4.9-12.9^{\circ} \mathrm{C}$, and the sum of effective temperatures is $59-86^{\circ} \mathrm{C}$. The vegetative period of species of the genus Calycanthus is quite long and was $179 \pm 7.73$ days in Calycanthus floridus, $189 \pm 5.72$ in Calycanthus occidentalis and 197.2 \pm 5.38 days in Calycanthus fertilis.

The average growth of the shoots and the growth of the leaves depends on the amount of rainfall and the average daily a temperature of the air. The plants of Calycanthus species have only one growth period.

The intensive growth was recorded in the third decade of May. In the period of complete fruiting of shrubs, the average growth of shoots directly depends on the intensity of flowering and the intensity of fruiting. It was revealed that in the conditions of the Volyn Forest-steppe the longest flowering period was observed in Calycanthus floridus - $79.8 \pm 3.0$ days; Calycanthus fertilis $-70.4 \pm 5.13$ days; Calycanthus occidentalis $-64 \pm 3.76$ days. Thus, it is proved that the rhythm of seasonal development of the studied species in the conditions of introduction is stable, regardless of the temperature fluctuations the plant bloom and fruit annually.

The necessary condition for the introduction and cultivation of plants is the study of the characteristics of their reproduction. The study of the ability of introduced species to seed and vegetative reproduction showed an average real seed production (10-15 seeds per fetus). Nevertheless, we consider the seed method of reproduction of these species to be the most promising for these species, since a high laboratory (up to $90 \%$ ) and field (85\%) germination is observed. As a result of the study of the ability of species to vegetative reproduction, it was established that for Calycanthus plants the characteristic average value of rooting of green cuttings is Calycanthus fertilis (29-32\%), Calycanthus floridus (29-31\%), Calycanthus occidentalis (20-23\%). When using a growth stimulant, the number of rooted cuttings increase by $14-25 \%$. Experiments on vegetative reproduction with lignified cuttings also showed no significant differences, although the survival rates were slightly higher: Calycanthus fertilis (35-42\%), Calycanthus floridus (33-41\%), Calycanthus occidentalis (22-25\%).

The change in the rhythm of the vital activity of plants is adaptive, and the more similar the new conditions of existence with the conditions of the natural range, the less noticeable the changes are and vice versa, the differences can be so significant that changes not only the rhythm of development, but also the life span of plants, their life form. Therefore, for the successful introduction of plants, it is important to have an objective assessment of their introductory possibilities, for which the method of climatic analogs is used. For the number of days with an air temperature above $5^{\circ} \mathrm{C}$, the forest steppe of Ukraine is similar to the Atlantic region of North America and certain regions of Transcaucasia; on the sum of average monthly positive temperatures - the north-eastern part of the Atlantic region of North America; on the humidity of the climate and the winter regime - the northern part of the Atlantic region of North America, Northeast China, Korea, the mountains of Central Asia. The established climatic analogs do not serve as absolute criteria for the species selection of woody plants for an introduction. The experience shows the possibility of increasing the adaptation of plants to the new conditions using various agrotechnical methods (artificial irrigation, shelter of the root system). This allows successfully to introduce species from the other regions, including the Pacific region of 
North America, under the conditions of the Forest-Steppe of Ukraine. The zone of the Forest-Steppe, to which the Volyn Upland belongs, is a zone of wide introduction (Кохно и Курдюк, 1994).

According to the assessment of the viability of species of the genus Calycanthus, the first group of prospects for further introduction includes plants of the type Calycanthus fertilis, the second group Calycanthus floridus, to the third - Calycanthus occidentalis (Table 1).

Table 1 Assessment of the viability of species of the genus Calycanthus L.

\begin{tabular}{|c|c|c|c|c|c|c|c|c|c|}
\hline \multirow[t]{2}{*}{ Species } & \multicolumn{7}{|c|}{ Viability, ball } & \multicolumn{2}{|c|}{ Total score } \\
\hline & Rsh & Wh & $\mathbf{H}$ & Fsh & Gsh & GD & $\mathbf{R}$ & $\Sigma$ & Gr \\
\hline C. fertilis & 20 & 25 & 10 & 3 & 5 & 25 & 7 & 95 & I \\
\hline C. floridus & 20 & 20 & 10 & 3 & 5 & 25 & 7 & 90 & II \\
\hline C. occidentalis & 15 & 15 & 5 & 3 & 5 & 25 & 7 & 75 & III \\
\hline
\end{tabular}

Rsh - the degree of annual ripening of shoots, Wh - winter hardiness, $\mathrm{H}$ - the conservation of plant habit, Fsh - the formation of shoots, Gsh - the regularity of shoot growth, GD - the capacity for generative development, $\Sigma$ - the sum of balls, $\mathrm{Gr}$ - perspective group

The success of acclimatization was assessed by determining the acclimatization number $(A)$. It is the sum of indicators of growth, generative development, winter hardiness and drought resistance of woody plants. The obtained acclimatization number showed that the high rate of acclimatization is characteristic for Calycanthus fertilis species $(A=91)$ and Calycanthus floridus $(A=81)$ and satisfactory for Calycanthus occidentalis $(A=68)$.

The reliable information in the analysis of adaptation of introduced plants is based on the fact that external seasonal changes that occur in plants integrally reflect complex qualitative processes in their organisms (Колісніченко, 2004).

Our scale for assessing the success of adaptation of woody plants testifies the dependence of the reproductive capacity of plants on winter hardiness and drought resistance and proves the significant role of these abiotic factors in the process of adaptation (Table 2 ).

Table 2 Success of adaptation of species of the genus Calycanthus L.

\begin{tabular}{|l|c|c|c|c|c|}
\hline Species & Wh & Dr & R & Ad. ind., \% & Ad. \\
\hline C. fertilis & 4 & 5 & 4 & 80 & IV \\
\hline C. floridus & 4 & 5 & 4 & 80 & IV \\
\hline C. occidentalis & 3 & 4 & 4 & 48 & II \\
\hline
\end{tabular}

Wh - winter hardiness, Dr - drought resistance, $\mathrm{R}$ - reproductive capacity, Ad. ind. - adaptive indicator, Ad. - adaptation level

As a result of the study, it was established that all species of the genus Calycanthus were adapted to the new conditions of the secondary range. A high level of adaptation (IV) was found in Calycanthus fertilis and Calycanthus floridus plants. Calycanthus occidentalis - medium level (II), but it should be noted that the adaptive indicator of this species is on the border of the indicators of the average and good level of adaptation.

It is known that for the creation of new landscaping facilities, modern highly abiotic and biotic resistant plants are needed. Particular preference is given to species that exhibit decorative for a long 
time. Species of the genus Calycanthus correspond to these requirements. The difference in plant their habitus, flowering and its duration, the shape and color of flowers, the shape and length of the leaves, provide an opportunity to create highly artistic compositions. The decorative properties of the species studied vary not only because of seasonal changes, but also in age. They essentially depend on the skillful composite application of woody vegetation in a certain landscape and on the characteristics of growing conditions. On the basis of our observations, investigated species of Calycanthus deserve attention and a score of 4 was obtained on the decorative scale, and therefore the decorative qualities are obvious, there is a clear preference for plants among ornamental plantations.

\section{Conclusions}

When summarizing the introduction, it was noted that the investigated species are winter-hardy and drought-resistant, regularly bloom and bear fruit, form full-fledged seeds. The assessment of the success of the adaptation of the studied species was IV and II points, which indicates the high and average degree of adaptability of the introduced plants to the new conditions of existence and the prospects of cultivating them in the conditions of the Volyn Upland.

The assessment of the success of the adaptation of the studied species was IV and II points, which indicates the high and average degree of adaptability of the introduced plants to the new conditions of existence and the prospects of their cultivation in the conditions of the Volyn Upland.

\section{References}

Базилевская, Н. 1964. Об основах теории адаптации растений при интродукции. Москва: Наука. 132 с.

Вехов, Н. 1957. Методы интродукции и акклиматизации древестных растений. Интродукция растений и зеленое строительство. Вып. 5. М. Л.: Наука, с. 93-107.

Ворошилов, В. 1960. Ритм развития у растений. Москва: Изд-во АН СССР. 136 с.

Гурский, А. 1957. Основные итоги интродукции древесных растений в СССР. М. Л.: Изд-во АН СССР. 301 с.

Калиниченко, А. 1978. Оценка адаптации и целесообразности интродукции древесных растений. Бюлетень ГБС, № 108. с. 3-8. ISSN 0366-502X.

Калініченко, О. 2003. Декоративна дендрологія: навч. посібник. Київ: Вища школа. 199 с. ISBN 966-642-145-3.

Колісніченко, О. 2004. Сезонні біоритми та зимостійкість деревних рослин. Київ: Фітосоціоцентр, c. 86-87. ISBN 966-306-056-7.

Кохно, Н., Курдюк, А. 1994. Теоретические основы и опыт интродукции древесных растений в Украине. Киев: Наукова думка. 185 с. ISBN 5-12-003567-1.

Лапин, П., Сиднева, С. 1973. Оценка перспективности интродукции древесных растений по данным визуальных наблюдений. Опыт интродукции древесных растений. Москва: Изд- во Главн. Ботан. сада АН СССР, с. 7-67.

Мамаев, С. 1991. Экологические аспекты интродукции растений. Экология и интродукция растений на Урале. Свердловск. с. 3-6.

Методика фенологических наблюдений в ботанических садах СССР. 1975. Москва. 27 с.

Морщихина, С. 1980. Семейство каликантовые (Calycanthaecae). Под ред. Тахтаджяна, А. Жизнь растений. Т.5 (1). Москва: Просвещение, с. 156-158. ISBN 978-5-458-27267-4.

Пятницкий, С. 1961. Практикум по лесной селекции. Москва: Сельхоз. литер., журн. и плакаты. 148 с.

Турецкая, Р. 1949. Приёмы ускоренного размножения растений путём черенкования. Москва: Изд-во AH CCCP. 167 c.

Хессайон, Д. 2006. Всё о декоративноцветущих кустарниках. Перевод с англ. Романовой, О. Изд. 2-е. Москва: Кладезь-Букс. с. 19. ISBN 5-93395-033-5. 